\title{
RELATO DE CASO: PACIENTE COM PERMANÊNCIA DE IgM POSITIVO PARA COVID-19
}

\section{CASE REPORT: PATIENT WITH POSITIVE IgM PERMANENCE FOR COVID-19}

AUTORES: Julyana Alves Barreto Rodrigues; Bianca Viana de Araújo Henriques.

FILIAÇÃO INSTITUCIONAL: Discentes do Curso de Graduação em Medicina da Faculdade de Medicina de Campos, Campos dos Goytacazes/RJ.

\section{RESUMO:}

Relata-se um caso de COVID-19, doença causada pelo novo coronavírus, que teve seu primeiro caso relatado em dezembro de 2019, em Wuhan na China, em paciente jovem, hipertenso, com permanência de IgM positivo no teste sorológico, mesmo após mais de 30 dias do início dos sintomas. Palavras-chave: IgM, COVID 19, Coronavírus, tratamento.

\section{ntrodução}

A COVID-19 doença causada pelo novo coronavírus, teve seu primeiro caso relatado em dezembro de 2019, em Wuhan na China. Atualmente já vitimou cerca de 1.044.269 óbitos no mundo e ainda segue ameaçando a saúde global. (SILVA et al., 2020; OPAS 2020)

O Coronavírus 2 da Síndrome Respiratória Aguda Grave (SARS-CoV-2) pertence ao gênero betacoronavirus, da subfamília Orthocoronavirinae, da família Coronaviridae. É um vírus envelopado (ou seja, há uma membrana lipídica de formato duplo e também proteínas inseridas) de fita única de RNA, em forma de coroa, devido as glicoproteínas em forma de espinhos, presentes em seu envelope. A sua entrada na célula hospedeira humana se dá a

\begin{abstract}
:
We report a case of COVID-19, a disease caused by the new coronavirus, which had its first case reported in December 2019, in Wuhan, China, in a young, hypertensive patient, with IgM positive in the serological test, even after more within 30 days of symptom onset.

Keywords: IgM, COVID 19, Coronavírus, treatment.
\end{abstract}

partir do auxílio da glicoproteína Spike (S) se ligar a enzima conversora de angiotensina 2 (ECA2) da célula hospedeira e a usá-la como aparato para replicação (CASCELLA et al., 2020; VELAVAN et al., 2020).

Nos dias atuais, é possível descrever fatores de risco a partir de grupos de risco que obtiveram uma evolução desfavorável, tais como, indivíduos com idade superior a 60 anos, portadores de doenças crônicas, como exemplo diabetes mellitus, hipertensão arterial sistêmica e/ou doenças pulmonares crônicas, tabagista de longa data como também os que fazem uso de quimioterápicos, corticosteroides de uso prolongado ou imunobiológicos. (SILVA et al., 2020). 
Para a definição do diagnóstico de COVID19 é preciso somar as informações clínicoepidemiológicas com exames Reação em Cadeia da Polimerase em Tempo Real (RT-PCR) e/ou sorologia quando possível e o exame de imagem com a tomografia computadorizada. RT-PCR é considerado o método padrão ouro e apresenta uma sensibilidade em torno de $63 \%$ quanto aos testes sorológicos tem maior sensibilidade, porém, somente após 7-9 dias de sintomas. (MERCÊS et.al., 2020)

Atualmente, vários medicamentos vêm sendo estudados para o tratamento clinico da COVID-19, dentre eles, pode-se destacar: Remdesivir, Ritonavir, Pirfenidona, Cloroquina/Hidroxicloroquina, Interferon-beta, Sarilumab. Entretanto, sabe-se hoje que a dexametasona foi o único medicamento que reduziu a mortalidade em pacientes hospitalizados. (HORBY et al., 2020; OLIVEIRA et al., 2020)

\section{Objetivos}

Entender a fisiopatologia da infecção por SARS-CoV-2 e conhecer os principais fatores de risco da COVID-19.

\section{Descrição do caso}

D.R.A, 27 anos, sexo masculino, hipertenso controlado, iniciou no dia 19/07 com quadro de dor de garganta, espirros, obstrução nasal e coriza. No dia seguinte, apresentou fraqueza e dor no corpo. No dia 22/07, os sintomas se agravaram e o paciente começou a apresentar tosse persistente e dor nas costas, na região torácica, irradiando para nuca, sendo potencializada com o esforço e atenuava com o repouso, então realizou o teste RT-PCR para COVID19 , testando positivo, no mesmo dia. No dia 23/07, iniciou quadro de febre alta de $38^{\circ} \mathrm{C}$, associada a calafrios, que permaneceu por 4 dias. Procurou assistência médica no mesmo dia que iniciou a febre e foi prescrito hidroxicloroquina e Azitromicina por 1 semana e Prednisona por 2 semanas. No dia 05/08, já não apresentava mais sintomas, com exceção da tosse e realizou novo teste, desta vez o teste rápido, dando positivo para IgM e IgG. O paciente continuou com tosse persistente, e no dia 28/08, 37 dias depois do início dos sintomas, realizou novo teste rápido, continuando a apresentar IgM e IgG positivos. Passou por avaliação médica e foi prescrito Moxifloxacino 400mg, Alegra e Acetilcisteína xarope por mais 14 dias. Por volta do 10 ㅇa dia de medicação a tosse desapareceu definitivamente.

\section{Conclusão}

Através deste relato é possível observar que não há um tempo preciso para a negativação do IgM em pacientes que tiveram a COVID-19, mesmo já apresentando IgG positivo há algum tempo. Além disso, ainda podemos perceber que o tratamento, por vezes, não é adequado para a condição do paciente, visto que o mesmo permanece com alguns sintomas, mesmo após o tratamento e período ativo da doença. Casos em que o tratamento clínico não foi suficiente, devem ser reavaliados para verificar a necessidade de novo ciclo de medicação.

\section{Referências Bibliográficas}

1. SILVA, Anderson Walter Costa et al. Perfil epidemiológico e determinante social do COVID-19 em Macapá, Amapá, Amazônia, Brasil. Revista Científica Multidisciplinar Núcleo do Conhecimento. Ano 05, Ed. 04, Vol. 04, pp. 05-27. Abril de 2020.

2. MERCÊS, Dulcilea Macedo das et.al. Doença de coronavírus 2019 (covid-19): mecanismos, diagnóstico diferencial e influência das medidas de intervenção. Research, SocietyandDevelopment. Agosto de 2020; v. 9, n. 8. 3. OLIVEIRA, Elton Henrique Alves de. Coronavírus: prospecção científica e tecnológica dos fármacos em estudo para tratamento da Covid-19. Cadernos de Prospecção - Salvador, v. 13, n. 2, Edição Especial, p. 412-423, abril, 2020. 
4. Horby et al. Dexamethasone in HospitalizedPatientswith Covid-19 - Preliminary Report. The New EnglandJournalofMedicine, Julho de 2020.

5. CASCELLA, Marco et al. Features, Evaluation and Treatment Coronavirus (COVID-19). Treasure Island, FL: StatPearls Publishing; 2020.

6. VELAVAN, TThirumalaisamy P. et al. The COVID-19 epidemic. Tropical Medicine \& International Health. v. 25, n.3, 2020.

7. Organização Pan-Americana da Saúde (OPAS).<disponível em: https://www.paho.org/pt/covid19>, acesso em 07 de outubro de 2020. 